\title{
Justification on the Selection of Revised Edition of Bloom's Taxonomy in the Levels of Oral Questioning in the Process of Teaching Mathematic in Malaysia
}

\author{
Muhammad Sofwan Mahmud, Aida Suraya Md. Yunus, Ahmad Fauzi Mohd Ayub, Tajularipin \\ Sulaiman
}

\begin{abstract}
This paper discusses a few taxonomies in education that are frequently used in various studies. Although there are other types of taxonomy that have been used by researchers in exploring the cognitive domain of the learning processes such as SOLO Taxonomy, Fink's Taxonomy and Marzano Taxonomy, yet the use of the Revised Edition of Bloom's Taxonomy was considered as the most justified for the study on the cognitive levels of oral questioning used by teachers in the teaching of mathematics. This paper will highlight comparison between all of these taxonomies and further justify the researcher's selection of the Revised Edition of Bloom's Taxonomy according to the suitability and needs of the study as well as the educational trends in Malaysia.
\end{abstract}

Keywords: Learning taxonomy, levels of oral questioning,

\section{INTRODUCTION}

In conducting a research on the levels of oral questioning, the analysis requires reference to a specific learning taxonomy to allow a detail examination of the kinds of questions posed in the teaching process. Besides, the usage of taxonomy also refers to the abstract and logical structure that serves as a catalyst for the construction of something that can expand the structure into a stronger and beneficial structure [1].

One of the research questions of this study was on the level of oral questions used by mathematics teachers in primary schools during the teaching process. In assisting the researcher to answer the research question, it is necessary to identify the most relevant cognitive taxonomy that can provide a perspective to study the research questions, narrow the scope and refine the focus of the study. A number of well-referred taxonomies have been deliberated in literature, including the original Bloom Taxonomy, the Revised Bloom Taxonomy, the SOLO Taxonomy, the Fink's Taxonomy and the Marzano Taxonomy. In order to explain the phenomenon studied, the researcher need to compare the taxonomies and to select the one that best fits the research needs and educational trends in Malaysia. It is important that the selected taxonomy serve as a framework in

Revised Manuscript Received on September 14, 2019.

Muhammad Sofwan Mahmud*, Faculty of Education, Nationa University of Malaysia, Bangi, Selangor, Malaysia. (Email: sofwanmahmud@ukm.edu.my)

Aida Suraya Md. Yunus, Faculty of Educational Studies, Universiti Putra Malaysia, Serdang, Selangor, Malaysia. (Email: aida@upm.edu.my)

Ahmad Fauzi Mohd Ayub, Faculty of Educational Studies, Universit Putra Malaysia, Serdang, Selangor, Malaysia. (Email: afmy@upm.edu.my)

Tajularipin Sulaiman, Faculty of Educational Studies, Universiti Putra Malaysia, Serdang, Selangor, Malaysia. (Email: tajulas@upm.edu.my. ) revised edition of Bloom's Taxonomy.

explaining the phenomena related to the cognitive level of oral questions used by teachers in the process of teaching mathematics.

Although several other taxonomies have been widely used in studies on questioning, this study had adopted the Bloom's Taxonomy after many comparisons were made. This taxonomy was introduced by Benjamin Bloom in a book entitled Taxonomy of Education Objectives: Handbook I: Cognitive Domain [2]. In [2] had listed six cognitive domains which are hierarchical, proceeding from knowledge, understanding, application, analysis, synthesis and evaluation as shown in Table I.

Table- 1: Cognitive Levels of Bloom Taxonomy [2]

\begin{tabular}{|c|l|}
\hline $\begin{array}{c}\text { Cognitive } \\
\text { Level }\end{array}$ & \multicolumn{1}{|c|}{ Description } \\
\hline Evaluation & $\begin{array}{l}\text { Making an evaluation that consider on } \\
\text { the internal or external factors, } \\
\text { interpreting and criticizing. }\end{array}$ \\
\hline Synthesis & $\begin{array}{l}\text { Integrate, combining ideas, solving } \\
\text { problems, make prediction, make } \\
\text { classification. }\end{array}$ \\
\hline Analysis & $\begin{array}{l}\text { Break down something complex into } \\
\text { smaller divisions, differentiate facts from } \\
\text { opinion, understanding the link between } \\
\text { divisions, recognizing organizational } \\
\text { structure. }\end{array}$ \\
\hline Application & $\begin{array}{l}\text { Applying the information in new } \\
\text { situation including solving problems } \\
\text { using principle, method, law, theory and } \\
\text { formula. Creating graph from the data. }\end{array}$ \\
\hline Comprehension & $\begin{array}{l}\text { Changing understanding from one form } \\
\text { to another, expressing the key ideas by } \\
\text { rephrasing into own verse, translating, } \\
\text { provide example of each concept and } \\
\text { interpreting draft. }\end{array}$ \\
\hline Knowledge \\
Recalling information, facts or \\
concepts.
\end{tabular}

In [3] reviewed the original Bloom's Taxonomy. It was observed that the learner's ability to synthesize/create requires the ability to evaluate, thus the highest two levels in the original Bloom's Taxonomy was adjusted to reflect cognitive levels in actual practice.

The original Bloom's taxonomy has been used for more

Published By: 
than half a century as a basis for designing educational goals, designing evaluations and assessments and being used in curriculum development around the world [4]. This cognitive framework has been found to be helpful for teachers in understanding, organizing and implementing educational objectives effectively.

\section{REVISED EDITION OF BLOOM'S TAXONOMY (2001)}

In this revised edition of Bloom's Taxonomy, in [3] had maintained the six cognitive levels, however the last two levels were revised and re-positioned. In addition, the keywords for each level was changed from nouns to verbs (Fig. 1). In the revised Bloom's Taxonomy, the levels of analysis and synthesis were integrated as the level of analysis. A new level, which is creating, was added as the highest level because the ability to create was found to be the most demanding and complex and it requires abilities in applying, analyzing and evaluating

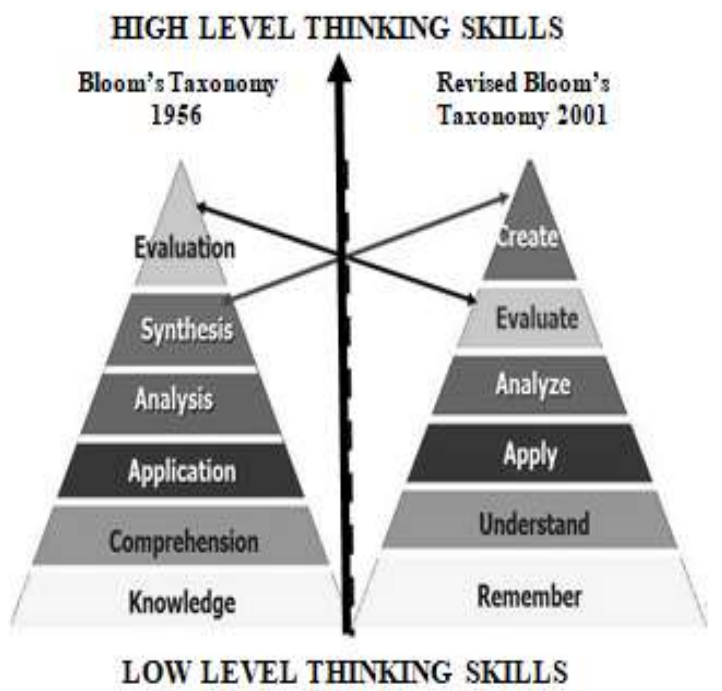

Fig. 1. Comparison of the original and revised Bloom's Taxonomy

Table II provides the descriptions for each of the cognitive levels in the revised edition.

Table- II: Cognitive levels of revised Bloom's

Taxonomy

\begin{tabular}{|c|c|}
\hline $\begin{array}{l}\text { Cognitive } \\
\text { Level }\end{array}$ & Description \\
\hline Creating & $\begin{array}{l}\text { Creating a creative and innovative } \\
\text { idea, product or method. }\end{array}$ \\
\hline Evaluating & $\begin{array}{l}\text { Making judgments and decisions } \\
\text { using knowledge, experience, skills, } \\
\text { values and then justify. }\end{array}$ \\
\hline Analyzing & $\begin{array}{l}\text { Break down the information into } \\
\text { smaller division for a better } \\
\text { understanding of connection between } \\
\text { them. }\end{array}$ \\
\hline Applying & $\begin{array}{l}\text { Applying knowledge, skills and } \\
\text { values in different situations to } \\
\text { accomplish something. }\end{array}$ \\
\hline Understanding & $\begin{array}{l}\text { Remembering information and can } \\
\text { explain ideas and concepts. }\end{array}$ \\
\hline Remembering & Recalling information, facts or \\
\hline
\end{tabular}

\section{\begin{tabular}{|l|l}
\hline & concepts.
\end{tabular}}

The Revised Bloom's Taxonomy also included another dimension of knowledge, which is metacognitive knowledge, to the three existing ones; factual knowledge, conceptual knowledge, and procedural knowledge. Factual knowledge refers to the basic elements students must know to be acquainted with a discipline or in solving problems, whereas conceptual knowledge deals with knowledge of concepts principles etc. and the understanding of relationships between them. Procedural knowledge denotes knowledge of procedures to do something which include use of skills, algorithms, techniques, and methods. The newly added dimension, which is metacognitive knowledge, is the highest level of knowledge and it requires awareness and knowledge of one's own cognition. Table III shows the mapping of four dimensions of knowledge to the types of knowledge.

Table- III: Mapping of dimensions of knowledge to knowledge types

\begin{tabular}{|c|c|}
\hline $\begin{array}{c}\text { Dimension of } \\
\text { Knowledge }\end{array}$ & Type \\
\hline Factual knowledge & $\begin{array}{l}\text { Knowledge on terminology } \\
\text { Detailed knowledge of event, } \\
\text { people, time and so on }\end{array}$ \\
\hline Conceptual \\
knowledge & $\begin{array}{l}\text { Knowledge on category } \\
\text { Knowledge of principle and } \\
\text { generalization } \\
\text { Knowledge of theory, model } \\
\text { and structure }\end{array}$ \\
\hline Procedural & $\begin{array}{l}\text { Algorithm knowledge } \\
\text { Methodological knowledge } \\
\text { Knowledge }\end{array}$ \\
& using procedure \\
\hline Metacognitive & $\begin{array}{l}\text { Strategic knowledge } \\
\text { Knowledge on criteria for } \\
\text { knowledge } \\
\text { operation conitive } \\
\text { Knowledge of yourself }\end{array}$ \\
\hline
\end{tabular}

In the Revised Edition of Bloom's Taxonomy, knowledge dimension and cognitive process dimension are found to be separated and this is different from the original Bloom's Taxonomy that combines the knowledge dimension with cognitive process dimension. Thus, this indirectly makes the Revised Edition of Bloom's Taxonomy more explicit and indirectly extends the scope of both dimensions [4]. In addition, it also indirectly helps to assess and evaluate the learning process better where mapping of knowledge and cognitive process can be implement effectively to improve and intervene the learning process.

\section{SOLO TAXONOMY}

The SOLO Taxonomy which is the abbreviation for Structure of the Observed Learning Outcome, was introduced by John Biggs and Kevin Collis in 1982 in New York. The SOLO Taxonomy in the book entitled "Evaluating the quality of learning: The SOLO Taxonomy" written by [5] classifies student learning outcomes in terms 
of complexity and It is designed as a tool for assessing the quality of student response to a task. Thus, the quality of achievement of the cognitive process measured is solely based on the quality of the answers given by the students. This taxonomy can measure the ability of students to solve a problem by comparing the actual answer with the answer given by the student. In this context, teachers and students can facilitate the formation of learning outcome easier. This taxonomy divided into three levels of knowledge which are surface knowledge consisting of uni-structural level and multi-structural level, deep knowledge consisting of relational level and conceptual knowledge that consist of extended abstract levels. Therefore, there are five levels in SOLO Taxonomy:

\section{A. Pre-Structural Level}

In this level, students do not understand the idea yet and they need help in getting started. They have very little knowledge on the topic being studied and the knowledge is in separate and unrelated units which it does not provide any concept at all and have no meaning

\section{B. Uni-Structural Level}

At this stage, student have a relevant idea of a clear and simple relationship between one concept and another but they are not fully understand the concept. This is because they have limited knowledge of the topic.

\section{Multi-Structural Level}

At this stage, students have some relevant ideas and understand some of the components but they are still separate from each other and have not formed a comprehensive understanding. Some simple relationships have already been established but the meta-cognition aspect has not been reached at this stage.

\section{Relational Level}

At this stage, students are able to make connection and integrate the facts with theories, actions and goals. Besides, students also can demonstrate the understanding of several components of a single concept unit, understand the function of each component as a whole and been able to apply a concept to similar situations at this stage.

\section{E. Extended Abstract Level}

At this stage student may connect the concepts in different directions at a higher levels and can develop it to generalize a new topic.

\section{FINK TAXONOMY}

The Fink Taxonomy or also known as Taxonomy of Significant Learning introduced by [6] is a taxonomy that is quite different from Bloom's Taxonomy and the SOLO Taxonomy where Fink Taxonomy is a taxonomy that has no hierarchy. The taxonomy consists of three affective aspects namely human dimension, caring and learning how to learn. Fink attempted to develop this taxonomy because there is one element that does not exist in Bloom's taxonomy which is the metacognitive element since Bloom's Taxonomy focuses more on the cognitive domain. There are six dimensions of Fink's taxonomy namely:

\section{A Foundational Knowledge Dimension}

Involves in understanding and remembering certain information and ideas.

\section{B Application Dimension}

Consider critically, creatively and practically; divide the problem into smaller units to solve the problem.

\section{Integrating Dimension}

Connecting ideas, people and real life.

\section{Human Dimension}

Learn about changes in a person, understand and interact with others.

\section{E Caring Dimension}

Caring Dimension: Identify the changes in one's feelings, interests and values.

\section{E Learning How to Learn Dimension}

Becoming a better and a self-directed student.

An important feature of this taxonomy is that it is not hierarchical but rather emphasizes relationship and even interactive. Fig. 2 illustrates the interactive nature of this taxonomy. This more dynamic diagram shows that each type of learning is related to another type of learning and when student achieves one learning it is likely that student can achieve another learning simultaneously [6].

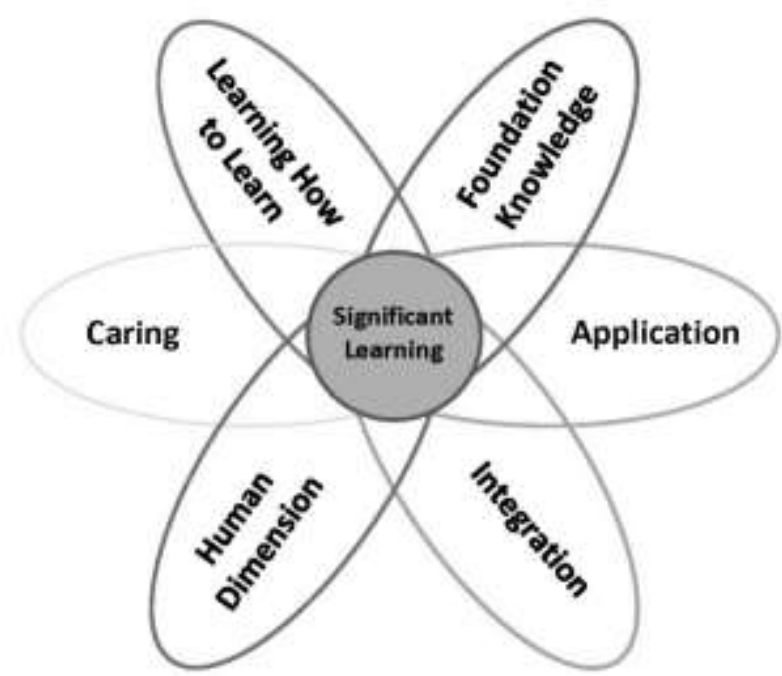

Fig. 2. Fink's Taxonomy of significant learning [6]

\section{MARZANO TAXONOMY}

Robert Marzano is a well-known researcher in education field who has proposed a taxonomy called A New Taxonomy of Educational Objectives [9], [11]. This taxonomy was developed to respond to the weaknesses in Bloom's Taxonomy that are widely used today. The thinking skills model introduced by Marzano combines variety of factors that influence how students think and provides more research-based theories to help teachers improve the thinking skills of student. 
Table- IV: System and domain of Marzano Taxonomy

\begin{tabular}{|c|c|c|}
\hline System & Level & Justification \\
\hline \multirow[t]{4}{*}{$\begin{array}{l}\text { Cognitive } \\
\text { System }\end{array}$} & Retrieval & $\begin{array}{l}\text { The process of } \\
\text { recalling } \\
\text { knowledge or } \\
\text { information without } \\
\text { understanding it. }\end{array}$ \\
\hline & 2.Comprehension & $\begin{array}{l}\text { The process of } \\
\text { synthesizing, } \\
\text { following } \\
\text { sequences or steps } \\
\text { and using } \\
\text { representation or } \\
\text { example to aid in } \\
\text { initial } \\
\text { understanding. }\end{array}$ \\
\hline & 3. Analyze & $\begin{array}{l}\text { The process of } \\
\text { accessing and } \\
\text { testing } \\
\text { knowledge the by } \\
\text { comparing the } \\
\text { differences, finding } \\
\text { similarities, } \\
\text { classifying, } \\
\text { analyzing errors, } \\
\text { generalizing and } \\
\text { logically } \\
\text { determining the } \\
\text { cause and effect. }\end{array}$ \\
\hline & 4. Utilization & $\begin{array}{l}\text { The process that } \\
\text { use knowledge to } \\
\text { make decisions, to } \\
\text { solve problems and } \\
\text { to investigate } \\
\text { problems. }\end{array}$ \\
\hline $\begin{array}{l}\text { Metacognitive } \\
\text { System }\end{array}$ & $\begin{array}{l}5 . \\
\text { Metacognitive }\end{array}$ & \begin{tabular}{l}
\multicolumn{1}{c}{ Process for } \\
monitoring the \\
learning goal that \\
have been set, \\
Implementation of \\
knowledge and \\
clarity of learning \\
process.
\end{tabular} \\
\hline Self-System & 6. Self & $\begin{array}{l}\text { The process of } \\
\text { identifying } \\
\text { responses and } \\
\text { emotional stimuli, } \\
\text { perception training, } \\
\text { motivation and the } \\
\text { benefits of having } \\
\text { confidence in early } \\
\text { knowledge. }\end{array}$ \\
\hline
\end{tabular}

The New Marzano Taxonomy is composed of three systems and a knowledge domain that are essential for the thinking and learning process (Table IV). The three systems are the Self-System, the Metacognitive-System, and the Cognitive-System. The Self-System decides whether to continue current behavior or engage in new activities when there is a choice of starting a new task; The Metacognitive System sets goals and keep track of how well they are achieving; The Cognitive System processed all the information needed, and the Knowledge Domain consists of information, mental procedures and physical procedures.

Overall, the taxonomy changed from (a) from simple to more complex processes involving information or procedures, (b) from lack of awareness to greater awareness of more control over knowledge processes including on how to build or use them and (c) from lack of personal involvement or commitment to a great, centralized trust and reflects of one's identity.

\section{DISCUSSION \& RESULTS}

\section{Justification on Revised Edition Bloom's Taxonomy} Selection

In this study, researchers have decided to use the Revised Bloom's Taxonomy [3] to look at the cognitive aspects of oral questioning used by the mathematics teachers in primary school. The reason that this taxonomy is adopted and not the others is to ensure that the questioning practices of the school teachers are in line with the emphasis on the higher order thinking skills (HOTS) in Malaysian schools as commissioned by the Ministry of Education. The identification of HOTS is based on the Revised Bloom's Taxonomy [7]. In addition, the taxonomy is also adopted in the Primary School Curriculum Standard as a guide in the implementation of the assessment standards [8]. Therefore, in this study, the researchers must adhere to the requirements for the implementation in the primary schools under the Ministry of Education. A study has also been conducted in schools under the Ministry of Education Malaysia that used the revised taxonomy [3] to explore the cognitive aspects of oral questioning activities. This indirectly strengthens the justification for the use of the Revised Bloom's Taxonomy to ensure that it is aligned to the ministry's vision.

Besides, the features of the Revised Edition of Bloom's Taxonomy that separate knowledge and cognitive processes from the original Bloom's Taxonomy have been found to be helpful for teachers in understanding the types of knowledge that students have not yet achieved. This will make it easier for teachers to plan and develop more specific questions. The old Bloom's taxonomy that does not separate elements of knowledge with elements of cognitive processes indirectly results in the lack of attention on procedural knowledge and metacognitive knowledge which are two types of knowledge found in the old Bloom's Taxonomy. In addition, the Revised Edition of Bloom's Taxonomy allows various questions to be asked for each type of cognitive process. This is because each of the cognitive levels contained in the Revised Edition of Bloom's Taxonomy is supported by 4 domains of knowledge which are factual, conceptual, procedural and metacognitive. Thus, this indirectly explains the justification for the usage of the Revised Edition of Bloom's Taxonomy in this study.

Apart from that, the use of the Revised Edition of Bloom's Taxonomy also has a positive impact on the 
learning objectives which greatly help teachers in formulating and planning oral questions at appropriate level to measure and assess students' achievement [14]. Therefore, by considering the relevance in terms of the type of knowledge and the type of cognitive processes found in the Revised Edition of Bloom's Taxonomy, it can assist teachers in developing a better oral questioning as the types of knowledge and cognitive processes highlighted are clear enough.

In addition, the comparison between the Revised Edition of Bloom's Taxonomy and the SOLO Taxonomy shows that the Revised Edition of Bloom's Taxonomy used in assessing students' cognitive aspects through the use of questions while the SOLO Taxonomy is often used in classifying and assessing the quality of students' answer in which the students' response level is evaluated by the quantity, quality and the relationship between the ideas contained in the response or answer given by the students. Returning to the main focus of this study which is to study on the aspects of oral questioning, the use of the Revised Edition of Bloom's Taxonomy is more relevant to this study where the cognitive processes in the questioning process can be viewed deeper for each cognitive level within the Bloom's Taxonomy, while the SOLO Taxonomy focuses more on the students responses. Although the oral questioning process definitely involves students' answers or responses, it is not the main focus of this study.

Besides, one of the important things in this study is the level of oral questioning. Thus, the Fink Taxonomy, which is a non-hierarchical Taxonomy will make it difficult for researchers to choose this taxonomy over the Revised Edition of Bloom's Taxonomy. Besides, having the level of cognitive process that will facilitate the researchers to conduct this study is the key feature that indirectly leads to the Bloom's Taxonomy selection. In addition, the Fink's taxonomy is also not focused on the cognitive aspect but rather on the affective aspect and that is one of the main purposes of Fink's attempt to develop this taxonomy since he argues that there is one element that does not exist in the Bloom's taxonomy which is the metacognitive element due to the Bloom's Taxonomy that focuses more on the cognitive domain.

As for the Marzano Taxonomy, the 3 systems emphasized in the taxonomy are the cognitive system, the metacognitive system and the self-system, which indirectly show the strength of the Marzano Taxonomy compared to the Revised Edition of Bloom's Taxonomy that only emphasizes on the cognitive aspect. [9] stated that Marzano Taxonomy has several unique features which it clearly recognized the importance of the self-system in learning as well as the importance of metacognitive systems and the aspects of knowledge used in order to determine the educational goals [10]. The Marzano Taxonomy is also found to be very helpful in dealing with the problem solving aspect which is the key aspect in mathematical learning while providing a framework to identify the higher level of thinking skills [11]. Although the Marzano Taxonomy looks better than the Revised Edition of Bloom's Taxonomy, the Marzano Taxonomy is actually more complex in terms of application than the Revised Edition of Bloom's Taxonomy which is easier to apply and widely used. Besides, it is also explained by [11] that the limited use of the Marzano Taxonomy in various studies has resulted in the existence of the Revised Edition of Bloom's Taxonomy. In addition, the authors of the Revised Edition of Bloom's Taxonomy also mentioned that their taxonomy was more focused and linear on learning, teaching, and assessment. Thus, the Revised Edition of Bloom's Taxonomy is found to be more suitable for this study.

The Bloom's Taxonomy has been used as a reference in determining cognitive levels as it uses the cognitive level found in the Bloom's Taxonomy as the level of oral questions. This can be seen in other studies conducted previously by, for example, [12], [13]. The Ministry of Education Malaysia has also adopted this Bloom's Taxonomy as a reference in conducting assessment to measure students' achievement [14]. Table V shows the purposes of oral questions that are customized according to the levels in the Revised Edition of Bloom's Taxonomy.

Table- V: The purposes of oral questions based on the Bloom's Taxonomy levels

\begin{tabular}{|c|c|}
\hline $\begin{array}{l}\text { Question } \\
\text { Level }\end{array}$ & Purposes of Oral Questions \\
\hline $\begin{array}{l}\text { Rememberin } \\
\mathrm{g}\end{array}$ & $\begin{array}{l}\text { Oral questions that require students to } \\
\text { remember the content of the lesson such } \\
\text { as definition, formula and principle. }\end{array}$ \\
\hline $\begin{array}{l}\text { Understandin } \\
\mathrm{g}\end{array}$ & $\begin{array}{l}\text { Questions that encourage students to } \\
\text { understand the meaning of and } \\
\text { definition in their own words and } \\
\text { explanation. }\end{array}$ \\
\hline Applying & $\begin{array}{l}\text { Questions that require student to use } \\
\text { information in a new context to solve } \\
\text { problem, answer question or perform } \\
\text { other tasks. Use information such as } \\
\text { rules, principles, formulas, theories, } \\
\text { concepts or procedures. }\end{array}$ \\
\hline Analyzing & $\begin{array}{l}\text { Oral questions that require students to } \\
\text { simplify their understanding in order to } \\
\text { see the difference, shape and so on. }\end{array}$ \\
\hline Evaluating & $\begin{array}{l}\text { Questions that require students to } \\
\text { formulate and generate new ideas, } \\
\text { pattern and structure. }\end{array}$ \\
\hline Creating & $\begin{array}{l}\text { Questions that use a set of criteria } \\
\text { that is either established by the student } \\
\text { or determined by the teacher in order to } \\
\text { achieve a based judgement. }\end{array}$ \\
\hline
\end{tabular}

Each level of question given by the teachers has its own function and purpose and should be used based on the learning needs. In this study, the level of question used can reflect the practice of oral questioning among the teachers as an effort to improve the higher order thinking skills of students. This is parallel with the intention of the Ministry of Education Malaysia that wishes to use oral questioning as a tool to improve students' level of thinking in order to compete globally. 


\section{REFERENCES}

1. N. A. Nik Pa, Penghasilan Disertasi Berkualiti dalam Pendidikan Matematik. Kuala Lumpur: Universiti Malaya Press, 2014.

2. B. S. Bloom, Taxonomy of Educational Objectives. Handbook I: Cognitive Domain Text. New York: David McKay, 1956.

3. L. W. Anderson and D. R. Krathwohl, A Taxonomy for Learning, Teaching, and Assessing: A Revision of Bloom's Taxonomy of Educational Objectives. London: Longman, 2001.

4. A. Widodo, "Taksonomi tujuan pembelajaran," J. Pendidik., vol. 4, pp. 61-69, 2005.

5. J. B. Biggs and K. F. Collis, Evaluating the Quality Of Learning: The SOLO Taxonomy (Structure of the Observed Learning Outcome). Massachusetts: Academic Press, 2014.

6. L. D. Fink, Creating Significant Learning Experiences: An Integrated Approach to Designing College Courses. New Jersey: John Wiley and Sons, 2013.

7. Bahagian Pembangunan Kurikulum, Bahan sumber peningkatan kemahiran berfikir aras tinggi matematik: Panduan penggunaan soalan Programme for International Student Assessment (PISA). Putrajaya: Kementerian Pendidikan Malaysia, 2013.

8. N. Kassim and E. Zakaria, "Integrasi kemahiran berfikir aras tinggi dalam pengajaran dan pembelajaran matematik: Analisis keperluan guru," Persidangan Serantau Siswazah Pendidikan, 2013.

9. R. J. Marzano and J. S. Kendall, The New Taxonomy of Educational Objectives. California: Corwin Press, 2006.

10. M. E. Martinez, Learning and Cognition: The Design of the Mind. London: Pearson, 2017.

11. J. Irvine, "A comparison of revised Bloom and Marzano's new taxonomy of learning," Res. High. Educ., vol. 33, pp. 1-16, 2017.

12. L. R. Larson and M. D. Lovelace, "Evaluating the classroom environments: Are we asking the right questions?," J. Excell. Coll. Teach., vol. 24, no. 1, pp. 105-122, 2013.

13. S. A. Mutalib and J. Ahmad, "Kepelbagaian aras soalan lisan dalam pentaksiran formatif bagi subjek geografi," J. Teknol., vol. 59, no. 1, pp. 103-108, 2012.

14. M. S. Mahmud, A. S. M. Yunus, A. F. M. Ayub, and T. Sulaiman, "Case study of the level of oral questioning used by teachers in formative assessment during the mathematics teaching process in primary school," Reli. Rev. Ciencias Soc. y Humanidades., vol. 4, no. 18, pp. 515-522, 2019.

\section{AUTHORS PROFILE}

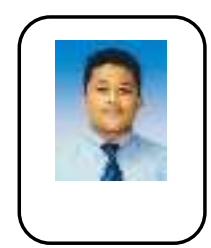

Muhammad Sofwan Mahmud is a lecturer in mathematics education at the National University of Malaysia. He holds a bachelor's and master's degree in mathematics education. $\mathrm{He}$ is currently pursuing a doctorate in mathematics education at Universiti Putra Malaysia. To date he has published several publications that focus on pedagogy and teaching mathematics. Accordingly, he has won several publishing awards and has won several teaching innovation competitions at various levels.

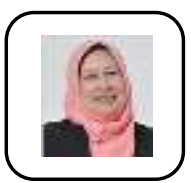

Dr Aida Suraya Md Yunus is a Professor of Mathematics Education and currently, she is the Dean of the Faculty of Educational Studies of Universiti Putra Malaysia (UPM). Prior to the appointment as dean, she Development of UPM and Chairman for the Council for Directors/Heads of Teaching Learning Centres of Public Universities. Dr Aida Suraya is an associate researcher with the lnstitute of Mathematical efficacy of questioning strategies in lecture-based was the Director of the Centre for Academic

Research and fellow of the National Higher Education Research Institute. She has collaborated with the Research lnstitute of Higher Education (RIHE) of Hiroshima University on a project on Academic Profession in Asia (APA). She did two projects with the Education Research Institutes Networks (ERl-Net) of UNESCO Bangkok; i.e. (i) Transition from school to higher education (ii) Promotion of teaching personnel in higher education. Currently, she leads a project with the lnnovative Research Universities of Australia to develop Criteria and Standards for Effective Teaching in Higher Education. She is recognized as a teaching and learning expert by the Ministry of Higher Education Malaysia. She is part of several task force committees including the Deputy Chairman for the Development of Criteria for Award of HICOE (Higher Institution Centre of Excellence) for Teaching and Learning, task force for realizing Shift \#9 of the Malaysian Education Blueprint on globalized online learning, and the National Committee Member for MOOC Development. The Malaysian Qualifications Agency (MOA) has engaged her expertise in developing the Guideline for Credit Transfer for MOOC and Guideline for Good Practices: Assessment of Students. She is also a Master Trainer of the Malaysian Higher Education Leadership Academy (AKEPT) for teaching and learning in higher education. She is also one of the writers for the Commonwealth document on Quality Standards in Education. She has done numerous training programmes on outcome-based education, assessment of learning outcomes, curriculum development and teaching and learning in higher education for several higher learning institutions (MOA, AKEPT, UPM, UPNM, USIM, UNIMAS, UTEM, UNIMAP, UMS, and polytechnics).

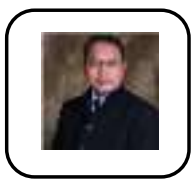

Ahmad Fauzi Mohd Ayub career as an educator started when he was appointed as a Matriculation teacher at Universiti Putra Malaysia upon completion of his Diploma of Education in 1994. However, in 1998 , following a policy change by the Ministry of Education, the Matriculation Centre in Universiti Putra Malaysia was closed. This marked a new phase in Ahmad Fauzi's career. He was transferred to the Faculty of Educational Studies in 2000. During that time, he pursued a Master of Information Technology degree at Universiti Teknologi MARA In compliance with the university requirement that lecturers needed to have the highest academic qualification, Ahmad Fauzi Mohd Ayub went on to pursue his studies at $\mathrm{PhD}$ level in 2003 at Universiti Kebangsaan Malaysia. As a post-graduate student, he developed an educational Multimedia Courseware for teaching and learning mathematics Calculus for diploma level. Upon completion of his studies, Dr. Ahmad Fauzi Mohd Ayub returned to Universiti Putra Malaysia in 2008 and was appointed senior lecturer. In July 2012, he applied for sabbatical leave to focus on his research and writing. He was appointed as Associate Professor in 1st February 2014.As a principal lecturer, Dr. Ahmad Fauzi Mohd Ayub taught 32 courses mainly related to information and communication technology in education, leading to the Bachelor of Education (Information Technology) degree. The courses he conducted involved both theoretical concepts and practical laboratory work. He also assisted students in their development of multimedia tools for educational use. Besides that, Dr. Ahmad Fauzi also taught other subjects such as testing and measurement courses and research methods. His courses at postgraduate level included Computer in Teaching and Learning, and Multimedia and Communication Technology, covering both instructional, as well as educational statistics courses. As a lecturer, Dr. Ahmad Fauzi Mohd Ayub received excellent service awards in 1997 1999, 2002, 2003, 2008, 2009, 2010 and 2011. He was named Excellent Young Researcher for 2010 and 2011 by the Institute for Mathematical Research. In 2010 he also received the Excellent Researcher award. Dr. Ahmad Fauzi has also been an active participant in science exhibitions, mostly at university level. He had participated in Research and Innovation Exhibitions in UPM since 2007, winning 16 medals, of which two were gold, 11 silver and two bronze. In 2011, he won a bronze medal at the Malaysian Technology Expo. Recently, he has won 1 silver and Bronze medal from Malaysian Technology Expo 2014

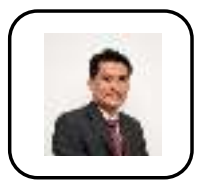

Dr. Tajularipin Sulaiman received his early education in Muar, Johor and continued his secondry education at the Sekolah Teknik Malacca. He continued his studies at the Centre for Foundation Studies in Science, Universiti Malaya in 1998. He obtained the Bachelor of Science with Education Degree in 1994 and Master of Education in 1998 from the University Malaya. He holds a doctoral degree in education from University Putra Malaysia. His area of specialization is in pedagogy, 
science education, and cognitive development. He has involved in courses in science education, thinking skills and primary education. He research interest is in the field of pedagogy and primary education especially in primary science. He has also presented papers in national and international conferences. 